\title{
Barium and Strontium Can Substitute for Calcium in Stimulating Nitric Oxide Production in the Endothelium of Canine Coronary Arteries
}

\author{
Jun Yamazaki, Fumihiro Ohara, Yoshinori Harada and Taku Nagao \\ Department of Toxicology and Pharmacology, Faculty of Pharmaceutical Sciences, University of Tokyo, Tokyo 113, Japan \\ Received December 8, 1994 Accepted January 26, 1995
}

\begin{abstract}
We investigated whether $\mathrm{Ba}^{2+}$ and $\mathrm{Sr}^{2+}$ can substitute for $\mathrm{Ca}^{2+}$ in stimulating the nitric oxide (NO) production and cause relaxation in vascular smooth muscle. $\mathrm{Ba}^{2+}$ and $\mathrm{Sr}^{2+}$, like $\mathrm{Ca}^{2+}$, relaxed $\mathrm{K}^{+}$depolarized canine coronary arteries in the presence of diltiazem. The $\mathrm{Ba}^{2+}$ - and $\mathrm{Sr}^{2+}$-induced relaxation was endothelium-dependent and was largely inhibited by $N^{G}$-monomethyl-L-arginine (L-NMMA) and $N^{G}$ nitro-L-arginine (L-NNA), but not by indomethacin. These cations increased cyclic GMP levels in the coronary artery to a similar extent, and the increment was completely abolished by L-NMMA. The relaxation induced by each cation was attenuated in the presence of a combination of propranolol, phentolamine and atropine, and L-NNA markedly inhibited any remaining relaxation. This indicates that these cations produce endothelium-dependent relaxation through NO production as well as the relaxation mediated by neurotrasmitters. The present study suggests that $\mathrm{Ba}^{2+}$ and $\mathrm{Sr}^{2+}$ can substitute for $\mathrm{Ca}^{2+}$ in the activation of the NO synthase pathway in the endothelium of canine coronary arteries.
\end{abstract}

Keywords: Barium, Strontium, Nitric oxide, Endothelium, Coronary artery

Nitric oxide (NO) synthases have been shown to catalyze the conversion of $\mathrm{L}$-arginine to NO radicals and $\mathrm{L}$ citrulline in the endothelium (1-3). An increase in intracellular $\mathrm{Ca}^{2+}$ is crucial for the activation of NO synthase in endothelial cells in the presence of calmodulin $(4,5)$. $\mathrm{Ba}^{2+}$ and $\mathrm{Sr}^{2+}$ have been shown to enter into cultured endothelial cells in response to bradykinin (6). However, no functional role of divalent cations in vascular endothelial cells has as yet been established in contrast to the situation in smooth muscle cells. $\mathrm{Ca}^{2+}$ and $\mathrm{Sr}^{2+}$ have been shown to cause an endothelium-dependent relaxation of canine coronary arteries contracted by prostaglandin (PG) $\mathrm{F}_{2 \alpha}$ in the absence of $\mathrm{Mg}^{2+}$, but $\mathrm{Ba}^{2+}$ did not cause such a relaxation (7). On the other hand, $\mathrm{Ba}^{2+}$ and $\mathrm{Sr}^{2+}$ have been shown to substitute for $\mathrm{Ca}^{2+}$ in the contraction of the rat tail artery (8). To our knowledge, no information has been published regarding any relaxant effect of $\mathrm{Ba}^{2+}$ produced through endothelial function.

Our previous study has shown that $\mathrm{Ca}^{2+}$ produces an endothelium-dependent relaxation of $\mathrm{K}^{+}$-depolarized canine coronary arteries in the presence of $\mathrm{Ca}$ antagonists $(9,10)$. These antagonists were useful in distinguishing the contractile effect of $\mathrm{Ca}^{2+}$ on vascular smooth muscle from its relaxant effect through endothelial function. This is because $\mathrm{Ca}$ antagonists block L-type $\mathrm{Ca}^{2-}$ channels in smooth muscle, but do not affect the influx of $\mathrm{Ca}^{2+}$ into endothelial cells (11). Under these conditions, an increase in $\mathrm{Ca}^{2+}$ in the endothelium should have induced production of NO from L-arginine and caused relaxation of the coronary arteries via an increase in cGMP levels. The present study aims to determine whether $\mathrm{Ba}^{2+}$ and $\mathrm{Sr}^{2+}$ can substitute for $\mathrm{Ca}^{2+}$ in producing relaxation through activation of the NO synthase pathway in endothelial cells.

In this study, we measured the tension of and cyclic GMP levels in canine coronary arteries. We demonstrated for the first time that $\mathrm{Ba}^{2+}$ caused strong relaxation of $\mathrm{K}^{+}$-depolarized coronary arteries through an NO-dependent mechanism in endothelial cells.

\section{MATERIALS AND METHODS}

\section{Chemicals}

Drugs used were: $\mathrm{CaCl}_{2} \cdot 2 \mathrm{H}_{2} \mathrm{O}$ and papaverine $\mathrm{HCl}$ (Wako Pure Chemicals Co., Ltd., Osaka); $\mathrm{BaCl}_{2} \cdot 2 \mathrm{H}_{2} \mathrm{O}$ (Kanto Chemical Co., Ltd., Tokyo); $\mathrm{PGF}_{2 \alpha}$ Tris salt, $N^{G}$ nitro-L-arginine (L-NNA) (Sigma, St. Louis, MO, USA); acetylcholine $\mathrm{Cl}$ (Ovisot; Daiichi Pharmaceutical Co., Ltd., Tokyo); diltiazem $\mathrm{HCl}$ and atropine sulfate (Tanabe Seiyaku Co., Ltd., Osaka); $\mathrm{SrCl}_{2} \cdot 6 \mathrm{H}_{2} \mathrm{O}$, L-argi- 
nine $\mathrm{HCl}$, sodium nitroprusside and EGTA (Nacalai Tesque Co., Ltd., Kyoto); phentolamine mesylate (Regitin; Ciba-Geigy Japan, Ltd., Takarazuka); $d l$-propranolol $\mathrm{HCl}$ (Sumitomo Chem. Co., Osaka). $N^{G_{-}}$ Monomethyl-L-arginine acetate (L-NMMA) was synthesized at the Organic Chemistry Research Laboratories (Tanabe Seiyaku Co., Ltd.). A stock solution of L-NNA $\left(3 \times 10^{-2} \mathrm{M}\right)$ was produced by dissolution in $0.1 \mathrm{~N} \mathrm{HCl}$ solution. The stock solution of $\mathrm{PGF}_{2 \alpha}$ Tris salt $\left(10^{-4} \mathrm{M}\right)$ was produced by dissolution in ethanol. Other compounds were dissolved in distilled water.

\section{Preparations}

Mongrel dogs weighing 8 to $18 \mathrm{~kg}$ were anesthetized with pentobarbital $\mathrm{Na}(30 \mathrm{mg} / \mathrm{kg}$, i.v.) and exsanguinated. The heart was immediately excised, and the circumflex branch of the left coronary artery (o.d.: $2.0-2.5 \mathrm{~mm}$ ) was dissected. The artery was freed from the surrounding connective tissue, and cut into ring segments, 3.5-4.5 $\mathrm{mm}$ long. Care was taken not to damage the intimal surface. When required, the endothelium was removed mechanically by gentle rubbing of the intimal surface with a cotton swab. The rings were suspended in organ chambers filled with physiological salt solution (PSS) maintained at $377^{\circ} \mathrm{C}$ and aerated with $95 \% \mathrm{O}_{2}-5 \% \mathrm{CO}_{2}$. Basal tension was adjusted to $1500 \mathrm{mg}$. The components of the PSS were: $147.2 \mathrm{mM} \mathrm{NaCl}, 5.4 \mathrm{mM} \mathrm{KCl}, 2.2 \mathrm{mM}$ $\mathrm{CaCl}_{2}, 1.0 \mathrm{mM} \mathrm{MgCl}, 14.5 \mathrm{mM} \mathrm{NaHCO}$ and $5.4 \mathrm{mM}$ dextrose ( $\mathrm{pH} 7.3-7.4)$. Isometric tension was measured with a strain gauge transducer (UL-10GR, UL-20GR; Minebea, Nagano) and recorded on a pen recorder (FBR252A; Toa Denpa, Tokyo).

\section{Isometric tension measurement}

After equilibration, aliquots of $40 \mathrm{mM} \mathrm{KCl}$ were repeatedly added to obtain steady responses from the artery rings. The presence of endothelium was determined by the vasodilative action of acetylcholine $\left(10^{-6} \mathrm{M}\right)$ in arteries precontracted by $2 \times 10^{-6} \mathrm{M} \mathrm{PGF}_{2 \alpha}$. The preparation was then repeatedly washed with $\mathrm{Ca}^{2+}$-free, $\mathrm{K}^{+}$-depolarizing PSS, which consisted of: $72.6 \mathrm{mM} \mathrm{NaCl}, 80.0 \mathrm{mM}$ $\mathrm{KCl}, 1.0 \mathrm{mM} \mathrm{MgCl}_{2}, 14.5 \mathrm{mM} \mathrm{NaHCO}$ and $5.4 \mathrm{mM}$ dextrose $(\mathrm{pH} 7.3-7.4)$. As no $\mathrm{Ca}^{2+}$-chelating agent was included, " $\mathrm{Ca}^{2+}$-free" means nominally $\mathrm{Ca}^{2+}$-free. All experiments were performed using $\mathrm{Ca}^{2+}$-free, $\mathrm{K}^{+}$-depolarizing PSS.

Diltiazem $\left(3 \times 10^{-6} \mathrm{M}\right)$ was added to block L-type $\mathrm{Ca}^{2+}$ channels in smooth muscle. $\mathrm{CaCl}_{2}, \mathrm{BaCl}_{2}$ or $\mathrm{SrCl}_{2}$ was added $10 \mathrm{~min}$ after the application of diltiazem. L-NMMA was added $20 \mathrm{~min}$ after the addition of each cation. LNNA and indomethacin were added $30 \mathrm{~min}$ and $15 \mathrm{~min}$ before the addition of each cation, respectively. Propranolol, phentolamine and atropine were added 15 min prior to the addition of each cation. At the end of the experiment, papaverine $\left(10^{-4} \mathrm{M}\right)$ was added to obtain maximum relaxation. Relaxation due to the cations was expressed as a percentage of the papaverine-induced relaxation. In experiments with endothelium-intact and endothelium-denuded arteries, the decrease in absolute tension was compared between the two groups.

\section{Cyclic nucleotide measurement}

Coronary artery ring segments were repeatedly washed with $\mathrm{Ca}^{2+}$-free, $\mathrm{K}^{+}$-depolarizing PSS $\left(37^{\circ} \mathrm{C}\right.$, aerated with $95 \% \mathrm{O}_{2}-5 \% \mathrm{CO}_{2}$ ). Ten minutes after the addition of diltiazem $\left(3 \times 10^{-6} \mathrm{M}\right)$, the segments were incubated with each divalent cation for $5 \mathrm{~min}$. L-NMMA was added 5 min before the addition of each cation. Immediately after incubation, each ring was frozen in liquid nitrogen and stored at $-70^{\circ} \mathrm{C}$. The frozen ring was homogenized with a glass homogenizer in $1.5 \mathrm{ml}$ ice-cold trichloroacetic acid $(6 \%)$, before centrifugation at $2,000 \times g$ for $10 \mathrm{~min}$ at $4^{\circ} \mathrm{C}$. The supernatant was collected and extracted with 4 volumes of water-saturated ether before being lyophilized. Each sample was resuspended with $100 \mu 150 \mathrm{mM}$ sodium acetate buffer (pH 6.2). Cyclic AMP and cyclic GMP levels were determined radioimmunochemically by a commercially available kit (Yamasa Shoyu Co., Choshi). The protein content was measured according to the method of Lowry et al. (12) using bovine serum albumin (Wako Pure Chemicals Co., Ltd.) as a standard. The cyclic nucleotide content was expressed as fmoles or pmoles per mg protein.

\section{Statistics}

Results are expressed as means \pm S.E. Statistical comparisons between groups were carried out using Student's $t$-test or Welch's $t$-test. Analysis of variance and Bonferroni's multiple $t$-test were used to compare a control group with more than two other treated groups. Differences at $\mathbf{P}<0.05$ were considered statistically significant.

\section{RESULTS}

Basal tone in nominally $\mathrm{Ca}^{2+}$-free PSS and divalent cations-induced contraction in canine depolarized coronary artery

The basal tension of the canine coronary artery was adjusted to approximately $1500 \mathrm{mg}$ in the nominally $\mathrm{Ca}^{2+}$. free, $80 \mathrm{mM} \mathrm{K}^{+}$-depolarizing PSS. Sodium nitroprusside $\left(10^{-6} \mathrm{M}\right), l$-noradrenaline $\left(10^{-6} \mathrm{M}\right)$ and papaverine $\left(10^{-4}\right.$ $M)$ reduced the basal tension by $532.5 \pm 55.9(n=4)$, $318.3 \pm 37.6(n=6)$ and $420 \pm 52.8 \mathrm{mg}(n=7)$, respectively. These results indicate that the canine coronary artery has active tone in $\mathrm{Ca}^{2+}$-free, $\mathrm{K}^{+}$-depolarizing PSS. EGTA $\left(2 \times 10^{-3} \mathrm{M}\right)$ decreased the tension by only 
a

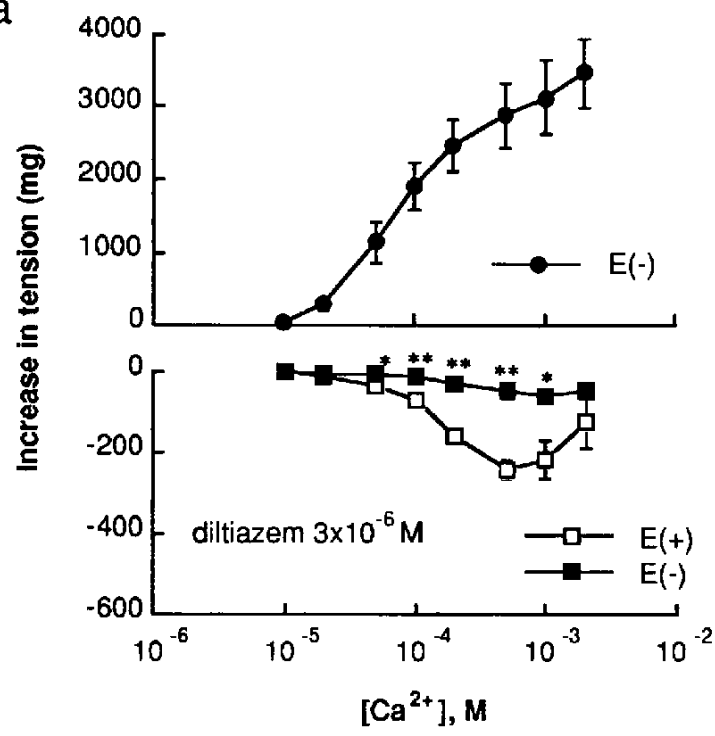

b

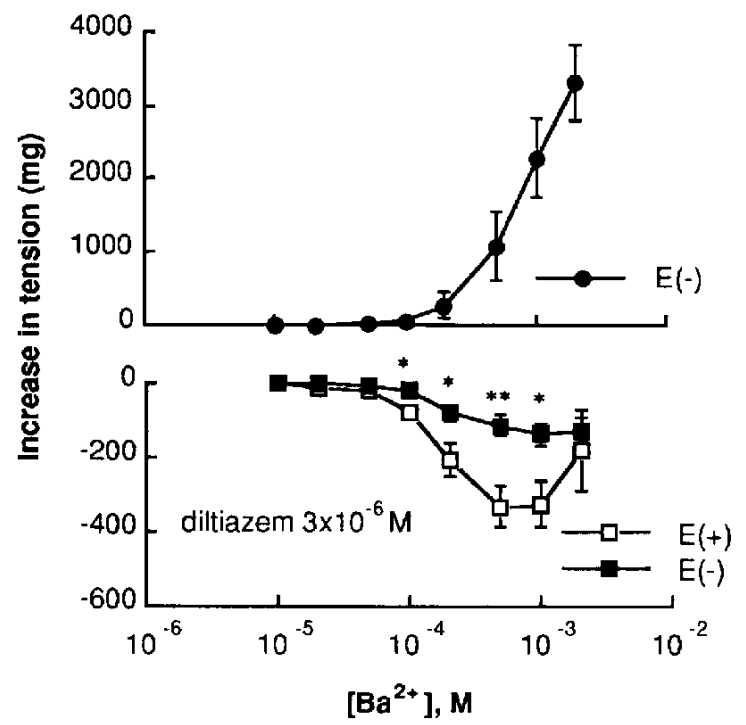

C

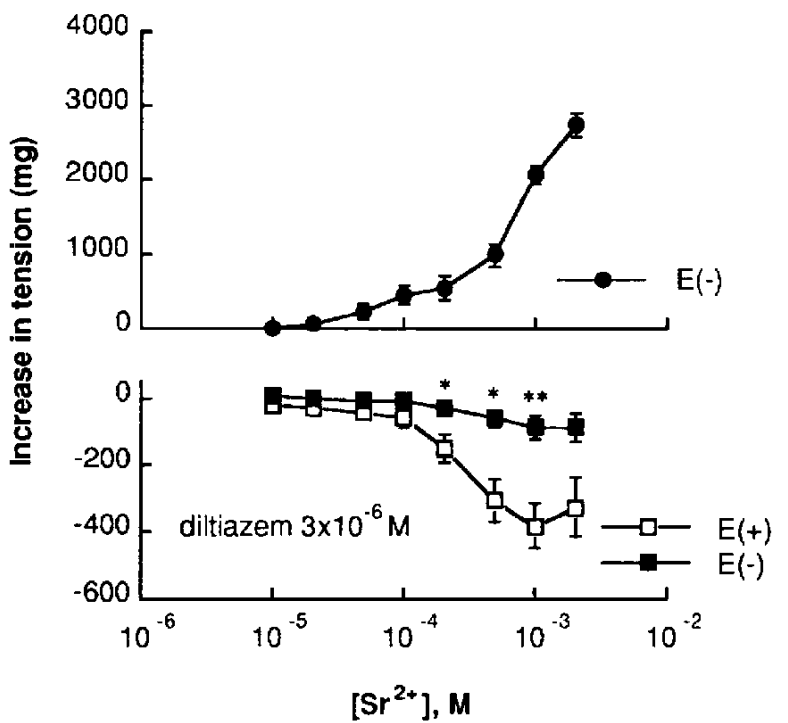

111.4 $\pm 26.9 \mathrm{mg}(\mathrm{n}=7)$. An L-type $\mathrm{Ca}^{2+}$ channel blocker, diltiazem $\left(3 \times 10^{-6} \mathrm{M}\right)$, did not significantly decrease the basal tension $(5.0 \pm 19.6 \mathrm{mg}, \mathrm{n}=8)$.

Under the above conditions, we compared the contractile response of the depolarized artery to $\mathrm{Ba}^{2+}$ and $\mathrm{Sr}^{2+}$ with that to $\mathrm{Ca}^{2+}$, in the absence of diltiazem. These cations caused contraction of endothelium-denuded rings in $80 \mathrm{mM} \mathrm{K}^{+}$-depolarizing PSS (Fig. 1). Maximal contraction did not differ in response to $\mathrm{Ca}^{2+}, \mathrm{Ba}^{2+}$ or $\mathrm{Sr}^{2+}$. However, $\mathrm{pEC}_{50}$ values $(\mathrm{n}=4)$ for $\mathrm{Ca}^{2+}, \mathrm{Ba}^{2+}$ and $\mathrm{Sr}^{2+}$ were different, being $4.0 \pm 0.1,3.2 \pm 0.1$ and $3.3 \pm 0.1$, respectively. The $\mathrm{pEC}_{50}$ value for $\mathrm{Ba}^{2+}$ and $\mathrm{Sr}^{2+}$ was significantly smaller than that for $\mathrm{Ca}^{2+}(\mathrm{P}<0.01)$.

\section{Divalent cations-induced relaxation in canine coronary arteries}

$\mathrm{Ba}^{2+}$ and $\mathrm{Sr}^{2+}$, like $\mathrm{Ca}^{2+}$, caused a significant concentration-dependent relaxation of the endothelium-intact rings in $\mathrm{K}^{+}$-depolarizing PSS in the presence of diltiazem $\left(3 \times 10^{-6} \mathrm{M}\right)$ (Fig. 1). $\mathrm{Ca}^{2+}$-, $\mathrm{Ba}^{2+}$ - and $\mathrm{Sr}^{2+}$-induced maximal relaxation was obtained at a concentration of $5 \times$ $10^{-4} \mathrm{M}, 5 \times 10^{-4} \mathrm{M}$ and $10^{-3} \mathrm{M}$, respectively. Relaxation was attenuated at higher concentrations of each cation. The $\mathrm{Ca}^{2+}-, \mathrm{Ba}^{2+}$ - and $\mathrm{Sr}^{2+}$-induced relaxation was significantly inhibited in the endothelium-denuded rings as compared with the intact rings in high concentration $\mathrm{K}^{+}$depolarizing PSS in the presence of diltiazem (Fig. 1).

\section{Effects of $L-N M M A, L-N N A$ and indomethacin}

$\mathrm{Ca}^{2+}\left(10^{-3} \mathrm{M}\right)$-induced relaxation was long-lasting in endothelium-intact arteries (Fig. 2a). Maximal relaxation was $70-80 \%$ of that induced by papaverine $\left(10^{-4} \mathrm{M}\right)$. This relaxation gradually decreased during exposure to $\mathrm{Ca}^{2+}$. Addition of L-NMMA $\left(10^{-4} \mathrm{M}\right)$ to the coronary artery rings during $\mathrm{Ca}^{2+}\left(10^{-3} \mathrm{M}\right)$-induced relaxation caused a rapid recovery from relaxation, and sometimes the tone increased above the level of tension before addition of $\mathrm{Ca}^{2+}$.

$\mathrm{Ba}^{2+}\left(10^{-3} \mathrm{M}\right)$-induced relaxation diminished gradually in endothelium-intact arteries, although more than $75 \%$ of the relaxation remained $60 \mathrm{~min}$ after the addition of $\mathrm{Ba}^{2+}$ (Fig. 2b). L-NMMA ( $10^{-4} \mathrm{M}$ and $3 \times 10^{-4} \mathrm{M}$ ) caused a significant decrease in the $\mathrm{Ba}^{2+}$-induced relaxation. This relaxation was not overcome after blockade by

Fig. 1. Divalent cation-induced contraction and relaxation of canine coronary artery. The arteries were suspended in $\mathrm{K}^{+}(80 \mathrm{mM})$ depolarizing, $\mathrm{Ca}^{2+}$-free PSS. $\mathrm{Ca}^{2+}$ (a), $\mathrm{Ba}^{2+}$ (b) or $\mathrm{Sr}^{2+}$ (c) was applied cumulatively to endothelium-intact $(E(+)$, clear $)$ and -denuded $(E(-)$, solid) arterial tissue in the presence (squares) or absence (circles) of diltiazem $\left(3 \times 10^{-6} \mathrm{M}\right)$. Each point represents the mean of 4-7 experiments with S.E. ${ }^{*} \mathrm{P}<0.05,{ }^{* *} \mathrm{P}<0.01$, compared with the intact artery in the presence of dittiazem. 

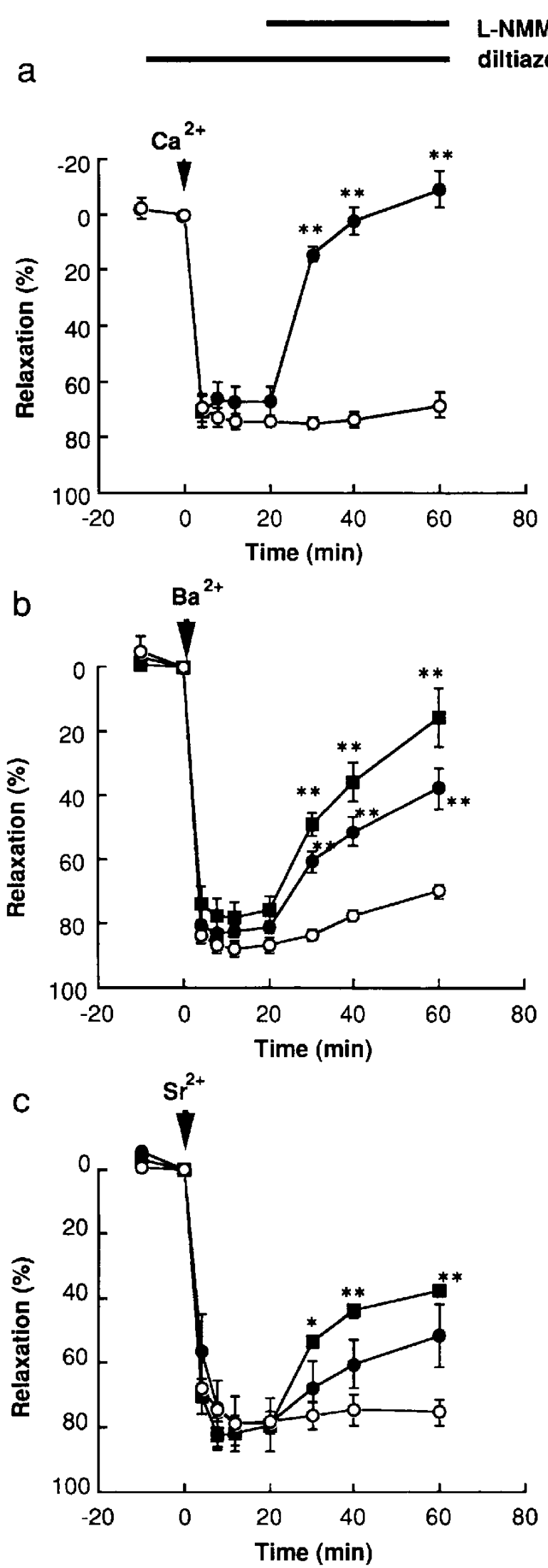

higher concentrations of L-NMMA.

$\mathrm{Sr}^{2+}\left(10^{-3} \mathrm{M}\right)$-induced relaxation was long-lasting, and it was maintained $60 \mathrm{~min}$ after the addition of $\mathrm{Sr}^{2+}$ (Fig. 2c). L-NMMA $\left(3 \times 10^{-4} \mathrm{M}\right.$ and $\left.10^{-3} \mathrm{M}\right)$ caused a decrease in $\mathrm{Sr}^{2+}$-induced relaxation. The relaxation remained partially present after blockade by a higher concentration of L-NMMA.

Pretreatment with L-NNA $\left(3 \times 10^{-5} \mathrm{M}\right)$ completely inhibited $\mathrm{Ca}^{2+}$-induced relaxation (Fig. 3a). L-NNA ( $3 \times$ $10^{-4} \mathrm{M}$ ) significantly inhibited $\mathrm{Ba}^{2+}-$ and $\mathrm{Sr}^{2+}$-induced relaxation, although relaxation remained partially present as with post-treatment by L-NMMA (Fig. 3, b and c). Indomethacin $\left(5 \times 10^{-6} \mathrm{M}\right)$ by itself increased the tension of the coronary arteries by about $75 \mathrm{mg}$ in $\mathrm{Ca}^{2+}$-free, high$\mathrm{K}^{+}$PSS, but did not affect $\mathrm{Ca}^{2+}, \mathrm{Ba}^{2+}$ - and $\mathrm{Sr}^{2+}$-induced relaxation (data not shown).

\section{Effects of neurotransmitter antagonists}

In the presence of a combination of propranolol $\left(10^{-6}\right.$ $\mathrm{M})$, phentolamine $\left(10^{-6} \mathrm{M}\right)$ and atropine $\left(10^{-6} \mathrm{M}\right), \mathrm{Ca}^{2+}$ still caused relaxation of depolarized coronary arteries (Fig. 3a). The degree of relaxation was smaller in the presence than in the absence of these antagonists. The remaining relaxation occuring in the presence of the combination was significantly inhibited by pretreatment with L-NNA. $\mathrm{Ba}^{2+}$ - and $\mathrm{Sr}^{2+}$-induced relaxation was markedly inhibited by the combination of these antagonists throughout the time course of the experiment (Fig. 3, b and $c$ ). In the presence of these antagonists, any remaining relaxation was significantly inhibited by pretreatment with L-NNA. However, some degree of $\mathrm{Ba}^{2+}$ - and $\mathrm{Sr}^{2+}$ induced relaxation remained after blockades of both the NO pathway and the neurotransmission.

\section{Divalent cation-induced increase in cyclic GMP levels}

Addition of $\mathrm{Ca}^{2+}, \mathrm{Ba}^{2+}$ or $\mathrm{Sr}^{2+}\left(10^{-3} \mathrm{M}\right)$ to the $\mathrm{Ca}^{2+}$. free PSS significantly increased the levels of cyclic GMP in $\mathrm{K}^{+}$-depolarized coronary arteries (Fig. 4). Pretreatment with L-NMMA $\left(3 \times 10^{-4} \mathrm{M}\right)$ significantly inhibited this increase. In contrast to the tension experiments, the $\mathrm{Ba}^{2+}$ - and $\mathrm{Sr}^{2+}$-induced increase in cyclic GMP levels was completely blocked by a modest concentration of $\mathbf{L}$ -

Fig. 2. Effects of L-NMMA on $\mathrm{Ca}^{2+}-, \mathrm{Ba}^{2+}$ - and $\mathrm{Sr}^{2+}$-induced relaxation of canine coronary artery. The arteries were suspended in $\mathrm{K}^{+}(80 \mathrm{mM})$-depolarizing, $\mathrm{Ca}^{2+}$-free PSS. $\mathrm{Ca}^{2+}$ (a), $\mathrm{Ba}^{2+}$ (b) or $\mathrm{Sr}^{2+}$ (c) $\left(10^{-3} \mathrm{M}\right)$ was applied $10 \mathrm{~min}$ after addition of diltiazem $\left(3 \times 10^{-6} \mathrm{M}\right)$. O: Control, $\mathrm{O}$ : L-NMMA $\left(10^{-4} \mathrm{M}\right), \mathbf{\square}:$ L-NMMA $\left(3 \times 10^{-4} \mathrm{M}\right)$. Percentage relaxation relative to the papaverine $\left(10^{-4} \mathrm{M}\right)$-induced relaxation is shown on the ordinate. Each agent was applied as indicated by the bar. Each point represents the mean of 3-6 experiments with S.E. ${ }^{*} \mathrm{P}<0.05,{ }^{* *} \mathrm{P}<0.01$, compared with the control group. 
L-NNA diltiazem

a
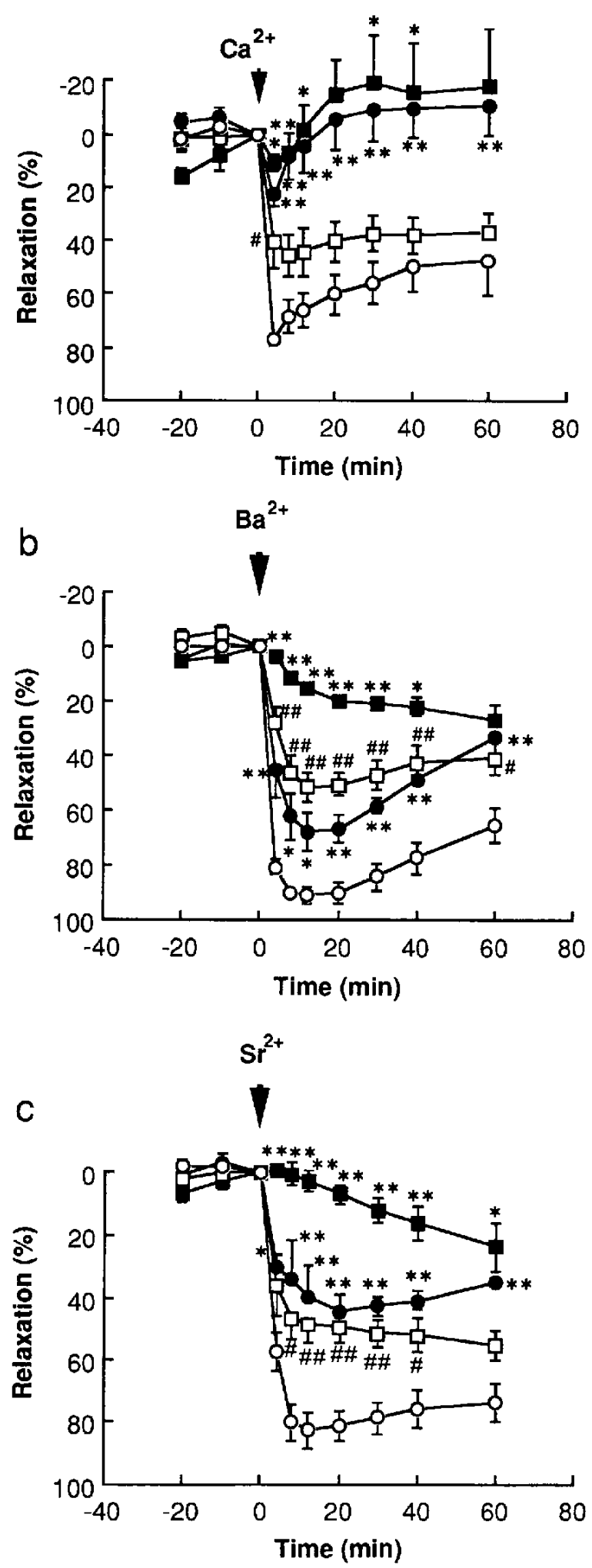

NMMA. In endothelium-denuded arteries, these cations did not increase cyclic GMP levels beyond the basal level in intact arteries $\left(\mathrm{Ca}^{2+} 10^{-3} \mathrm{M}, 146 \pm 19 \mathrm{fmol} / \mathrm{mg}\right.$; $\mathrm{Ba}^{2+}$ $10^{-3} \mathrm{M}, 83 \pm 9 \mathrm{fmol} / \mathrm{mg} ; \mathrm{Sr}^{2+} 10^{-3} \mathrm{M}, 82 \pm 8 \mathrm{fmol} / \mathrm{mg}$ ). These cations $\left(10^{-3} \mathrm{M}\right)$ caused no significant effects on cyclic AMP levels in endothelium-intact arteries (Fig. 4).

\section{DISCUSSION}

Substitution of $\mathrm{Ba}^{2+}$ and $\mathrm{Sr}^{2+}$ for $\mathrm{Ca}^{2+}$ in endothelial cells

The main finding of the present study is that $\mathrm{Ba}^{2+}$ and $\mathrm{Sr}^{2+}$ can substitute for $\mathrm{Ca}^{2+}$ in the activation of the NO synthase pathway in the endothelium. We have demonstrated for the first time that addition of $\mathrm{Ba}^{2+}$ causes relaxation of $\mathrm{K}^{+}$-depolarized canine coronary arteries in the presence of diltiazem. This relaxation was inhibited by removal of endothelial cells or by L-NMMA and L-NNA, both of which are inhibitors of NO synthase (13). Furthermore, addition of divalent cations increased the cyclic GMP levels in endothelium-intact arteries but not those in endothelium-denuded arteries. Therefore, synthesis of NO in endothelial cells is in part responsible for the $\mathrm{Ba}^{2+}$ and $\mathrm{Sr}^{2+}$-induced relaxation of $\mathrm{K}^{+}$-depolarized canine coronary arteries.

However, there were some differences in NO-dependent relaxation and cGMP production between the three cations, although they are all in the group of alkaline earth cations. $\mathrm{Ba}^{2+}$ - and $\mathrm{Sr}^{2+}$-induced relaxation was inhibited by NO synthase inhibitors to about half the control value, while $\mathrm{Ca}^{2+}$-induced relaxation was completely inhibited by these agonists. Nevertheless, all of these cations increased the cyclic GMP level to a similar extent, and this effect was completely inhibited by L-NMMA. These results indicate that $\mathrm{Ca}^{2+}$-induced relaxation is almost totally dependent on the NO pathway, whereas $\mathrm{Ba}^{2+}$ - and $\mathrm{Sr}^{2+}$-induced relaxation is largely, but not exclusively, dependent on this pathway.

Fig. 3. Effects of L-NNA on $\mathrm{Ca}^{2+}-, \mathrm{Ba}^{2+}-$ and $\mathrm{Sr}^{2+}$-induced relaxation of canine coronary artery in the presence or absence of a combination of propranolol, phentolamine and atropine. The arteries were suspended in $\mathrm{K}^{+}(80 \mathrm{mM})$-depolarizing, $\mathrm{Ca}^{2+}$-free PSS. $\mathrm{Ca}^{2+}$ (a), $\mathrm{Ba}^{2+}$ (b) or $\mathrm{Sr}^{2-}$ (c) $\left(10^{-3} \mathrm{M}\right)$ was applied $10 \mathrm{~min}$ after addition of diltiazem $\left(3 \times 10^{-6} \mathrm{M}\right)$ in the absence (circles) or presence (squares) of a combination of propranolol, phentolamine and atropine (each $10^{-6} \mathrm{M}$ ). The combination of these antagonists was applied $15 \mathrm{~min}$ before the addition of each cation. $\bigcirc, \square$ : Control, , $\square$ : L-NNA $\left(3 \times 10^{-5} \mathrm{M}\right.$ in panel $\mathrm{a}$ and $3 \times 10^{-4} \mathrm{M}$ in panels $\mathrm{b}$ and c). Percentage relaxation relative to the papaverine $\left(10^{-4} \mathrm{M}\right)$-induced relaxation is shown on the ordinate. Each agent was applied as indicated by the bar. Each point represents the mean of 3-6 experiments with S.E. ${ }^{*} \mathbf{P}<0.05,{ }^{* *} \mathrm{P}<0.01$, compared with the control group. ${ }^{\#} \mathrm{P}<0.05,{ }^{\# \#} \mathrm{P}<0.01$, compared with the group in the absence of propranolol, phentolamine and atropine. 

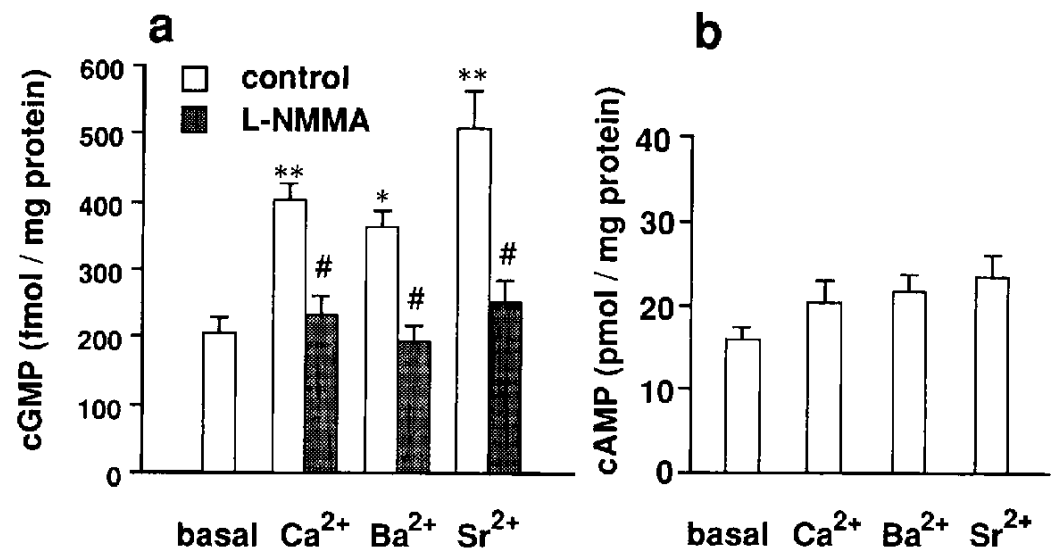

Fig. 4. Effects of divalent cations $\left(10^{-3} \mathrm{M}\right.$ for $5 \mathrm{~min}$ ) on tissue levels of cyclic GMP (a) and cyclic AMP (b) in endotheliumintact rings of canine coronary artery in the presence of diltiazem $\left(3 \times 10^{-6} \mathrm{M}\right)$. The arteries were incubated in $\mathrm{K}^{+}(80 \mathrm{mM})$ depolarizing, $\mathrm{Ca}^{2+}$-free PSS. L-NMMA $\left(3 \times 10^{-4} \mathrm{M}\right)$ was applied $5 \mathrm{~min}$ before the addition of each cation. Each point represents the mean of 5-9 experiments with S.E. ${ }^{*} \mathrm{P}<0.05,{ }^{* *} \mathrm{P}<0.01$, compared with each basal level. ${ }^{*} \mathrm{P}<0.05$, compared with the corresponding control for each cation.

The $\mathrm{Ca}^{2+}$-, $\mathrm{Ba}^{2+}$ - and $\mathrm{Sr}^{2+}$-induced relaxation was not inhibited by indomethacin, an inhibitor of cyclooxygenase. Furthermore, addition of these cations did not affect cyclic AMP levels. Thus, synthesis of prostacyclin as a mechanism for the relaxation could be excluded. Feletou and Vanhoutte (14) have suggested that another endothelium-derived relaxing substance, named endothelium-dependent hyperpolarizing factor (EDHF) (15), causes relaxation through hyperpolarization of the canine coronary artery. However, EDHF was not responsible for these cation-induced relaxations in this study because we used $\mathrm{K}^{+}(80 \mathrm{mM})$-depolarized arteries.

\section{Role of neurotransmitters}

Functional and histochemical studies have shown that adrenergic and cholinergic fibers innervate coronary arteries and that this mechanism is involved in the relaxation induced by electrical stimulation $(16,17)$. These fibers seem to have a role in $\mathrm{Ca}^{2+}, \mathrm{Ba}^{2+}$ - and $\mathrm{Sr}^{2+}$-induced relaxation. According to Nakazato and Onoda (18), $\mathrm{Ba}^{2+}$ and $\mathrm{Sr}^{2+}$ can substitute for $\mathrm{Ca}^{2-}$ in noradrenaline release induced by excess potassium in the vas deferens of the guinea pig. In the present study, $\mathrm{Ca}^{2+}-, \mathrm{Ba}^{2+}-$ and $\mathrm{Sr}^{2+}$-induced relaxation was attenuated by a combination of antagonists of $\beta$ - and $\alpha$-adrenoceptors and muscarinic receptors. Therefore, neurotransmitters released by these cations in part contribute to the relaxation of the coronary arteries. This may explain the small degree of relaxation that was observed in the endothelium-denuded artery as shown in Fig. 1. In the case of $\mathrm{Ca}^{2+}$, these fibers have an apparently minor role, since relaxation was overcome by treatment with L-NMMA and L-NNA in the absence of the antagonist combination.
In contrast to the situation with $\mathrm{Ca}^{2+}$, approximately $20 \%$ of the $\mathrm{Ba}^{2+}$ - and $\mathrm{Sr}^{2+}$-induced relaxation was maintained in coronary arteries treated with L-NNA in the presence of adrenergic and cholinergic antagonists, although the increase in cyclic GMP levels was completely blocked by L-NMMA. This may be due to differences in the extent of contraction of $\mathrm{K}^{+}$-depolarized coronary arteries induced by each cation, because the $\mathrm{pEC}_{50}$ from the concentration-response curve for $\mathrm{Ca}^{2}+$ was greater than those for $\mathrm{Ba}^{2+}$ and $\mathrm{Sr}^{2+}$.

\section{Differences in responses to divalent cations}

Both $\mathrm{Ca}^{2+}$ and calmodulin have been shown to be required for the constitutive NO synthase in the endothelium $(4,5,19-21)$. Thus, the affinity of divalent cations for calmodulin may be important for the activation of NO synthase. $\mathrm{Ca}^{2+}$ and $\mathrm{Sr}^{2+}$ have been shown to evoke the tyrosine fluorescence of calmodulin maximally at concentrations of approximately 7 moles $\mathrm{Ca}^{2+}$ and 40 moles $\mathrm{Sr}^{2+}$ per mole calmodulin (22). Therefore, $\mathrm{Sr}^{2+}$ may easily substitute for $\mathrm{Ca}^{2+}$ in the activation of calmodulin. However, $\mathrm{Ba}^{2+}$ has been reported to be completely ineffective in inducing the tyrosine fluorescence of calmodulin even at concentrations of 50 moles $\mathrm{Ba}^{2+}$ per mole calmodulin (22).

It remains unclear how $\mathrm{Ba}^{2+}$ is able to stimulate EDRF/NO release. One explanation is that $\mathrm{Ba}^{2+}$ itself may accumulate in endothelial cells at levels sufficient to compensate for the low affinity of $\mathrm{Ba}^{2+}$ for calmodulin, since it is not taken up into intracellular stores or readily removed from the cells. This explanation has also been discussed in previous studies concerning the calmodulindependent contraction of smooth muscle $(23,24)$ and 
$\mathrm{Ca}^{2+}$-ATPase in human erythrocytes (25). Another possibility is that $\mathrm{Ba}^{2+}$ may induce the release of $\mathrm{Ca}^{2+}$ from endothelial intracellular $\mathrm{Ca}^{2+}$ stores, as has been proposed for $\mathrm{Ba}^{2+}$-induced contraction in smooth muscle $(24,26)$. To determine the exact reason, further studies are needed on the relationship between $\mathrm{Ba}^{2+}$ concentrations and $\mathrm{Ba}^{2+}$-induced activation of $\mathrm{NO}$ synthase in endothelial cells.

\section{Active tone in depolarized coronary artery}

Under the conditions we used, depolarized canine coronary arteries possessed some active tone even in nominally $\mathrm{Ca}^{2+}$-free, $\mathrm{K}^{+}$-depolarizing PSS, since their tone was reduced by a NO-releasing agent, an adrenoceptor agonist and a smooth muscle relaxant. Extracellular $\mathrm{Ca}^{2+}$ is likely to contribute only partially to this active tone, since the basal tension remained after EGTA was applied. Thus, intracellular $\mathrm{Ca}^{2+}$ stores may play a role in generating this active tone. Although diltiazem did not decrease the basal tension in the present study, a much higher concentration than that necessary to inhibit the contraction evoked by the release of sequestered $\mathrm{Ca}^{2+}$ (27) might change the active tone. The exact mechanism underlying this tone requires further clarification, but it provides a useful bioassay system for the investigation of divalent cation-induced relaxation.

The present study has revealed that endothelial function can be regulated by $\mathrm{Ba}^{2+}$. Although the physiological relevance of this fact is uncertain, this study raises interesting questions such as what is the mechanism by which $\mathrm{Ba}^{2+}$ activates endothelial NO synthase and what is the concentration of $\mathrm{Ba}^{2+}$ necessary for its endothelial function? In conclusion, $\mathrm{Ba}^{2+}$ and $\mathrm{Sr}^{2+}$ were found to substitute for $\mathrm{Ca}^{2+}$ in producing $\mathrm{NO}$ in the endothelium and to relax canine depolarized coronary arteries through cGMP production.

\section{Acknowledgments}

The authors would like to thank Dr. Kohei Kikkawa for helpful discussions. This work was supported by a Grant-in-Aid for Scientific Research from the Ministry of Education, Science and Culture, Japan.

\section{REFERENCES}

1 Palmer RMJ, Rees DD, Ashton DS and Moncada S: L-Arginine is the physiological precursor for the formation of nitric oxide in endothelium-dependent relaxation. Biochem Biophys Res Commun 153, 1251 - 1256 (1988)

2 Mayer B, Schmidt K, Humbert P and Böhme E: Biosynthesis of endothelium-derived relaxing factor: a cytosolic enzyme in porcine aortic endothelial cells $\mathrm{Ca}^{2+}$-dependently converts L-arginine into an activator of soluble guanylyl cyclase. Biochem Biophys Res Commun 164, 678-685 (1989)

3 Pollock JS, Förstermann U, Mitchell JA, Warner TD, Schmidt
HHHW, Nakane M and Murad F: Purification and characterization of particulate endothelium-derived relaxing factor synthase from cultured and native bovine aortic endothelial cells. Proc Natl Acad Sci USA 88, 10480-10484 (1991)

4 Busse R and Mülsch A: Calcium-dependent nitric oxide synthesis in endothelial cytosol is mediated by calmodulin. FEBS Lett 265, 133-136 (1990)

5 Förstermann U, Pollock JS, Schmidt HHH, Heller $M$ and Murad F: Calmodulin-dependent endothelium-derived relaxing factor/nitric oxide synthase activity is present in the particulate and cytosolic fractions of bovine aortic endothelial cells. Proc Natl Acad Sci USA 88, 1788-1792 (1991)

6 Schilling WP, Rajan L and Strobl-Jager E: Characterization of the bradykinin-stimulated calcium influx pathway of cultured vascular endothelial cells. J Biol Chem 264, 12838-12848 (1989)

$7 \mathrm{Ku}$ DD: Divalent cation regulation of endothelial-dependent relaxation in coronary blood vessels. Microcirc Endothelium Lymphatics 5, 99-120 (1988)

8 Ebeigbe $\mathrm{AB}$ and Aloamaka $\mathrm{CP}$ : Barium and strontium as calcium substitutes for contractile responses in the rat tail artery. Comp Biochem Physiol 82C, 213-216 (1985)

9 Kikkawa K, Murata $S$ and Nagao T: Calcium antagonistic and spasmolytic activities of a new 1,5-benzothiazepine derivative in isolated canine and monkey arteries. Arzneimittelforschung 38, $526-531$ (1988)

10 Kikkawa K, Murata S and Nagao T: Endothelium-dependent calcium-induced relaxation in the presence of $\mathrm{Ca}^{2+}$-antagonists in canine depolarized coronary arteries. Br J Pharmacol 98, 700-706 (1989)

11 Colden-Stanfield M, Schilling WP, Ritchie AK, Eskin SG, Navarro LT and Kunze DL: Bradykinin-induced increases in cytosolic calcium and ionic currents in cultured bovine aortic endothelial cells. Circ Res 61, 632-640 (1987)

12 Lowry OH, Rosebrough NJ, Farr AL and Randall RJ: Protein measurement with the Folin phenol reagent. J Biol Chem 193, $265-275$ (1951)

13 Rees DD, Palmer RMJ, Hodson HF and Moncada S: A specific inhibitor of nitric oxide formation from L-arginine attenuates endothelium-dependent relaxation. $\mathrm{Br} J$ Pharmacol 96, 418-424 (1989)

14 Feletou M and Vanhoutte PM: Endothelium-dependent hyperpolarization of canine coronary smooth muscle. Br J Pharmacol 93, 515-524 (1988)

15 Chen G, Suzuki H and Weston AH: Acetylcholine releases endothelium-derived hyperpolarizing factor and EDRF from rat blood vessels. Br J Pharmacol 95, 1165-1174 (1988)

16 Toda $\mathrm{N}$ and Hayashi S: Responses of canine coronary arteries to transmural electrical stimulation and nicotine. Eur J Pharmacol 80, 73-81 (1982)

17 Denn MJ and Stone HL: Autonomic innervation of dog coronary arteries. J Appl Physiol 41, 30-35 (1976)

18 Nakazato $\mathrm{Y}$ and Onoda $\mathrm{Y}$ : Barium and strontium can substitute for calcium in noradrenaline output induced by excess potassium in the guinea-pig. J Physiol (Lond) 305, 59-71 (1980)

19 Lamas S, Marsden PA, Li GK, Tempst $P$ and Michel T: Endothelial nitric oxide synthase: Molecular cloning and characterization of a distinct constitutive enzyme isoform. Proc Natl Acad Sci USA 89, 6348-6352 (1992)

20 Janssens SP, Shimouchi A, Quertermous T, Bloch DB and 
Bloch KD: Cloning and expression of a cDNA encoding human endothelium-derived relaxing factor/nitric oxide synthase. J Biol Chem 267, 14519-14522 (1992)

21 Sessa WC, Harrison JK, Barger CM, Zeng D, Durieux ME, D'angelo DD, Lynch KR and Peach MJ: Molecular cloning and expression of a cDNA encoding endothelial cell nitric oxide synthase. J Biol Chem 267, 15274-15276 (1992)

22 Chao S-H, Suzuki Y, Zysk JR and Cheung WY: Activation of calmodulin by various metal cations as a function of ionic radius. Mol Pharmacol 26, 75-82 (1984)

23 Kreye VAW, Hofmann F and Mühleisen M: Barium can replace calcium in calmodulin-dependent contractions of skinned renal arteries of the rabbit. Pflugers Arch 406, 308-311 (1986)

24 Satoh S, Kubota $Y$, Itoh $T$ and Kuriyama $H$ : Mechanisms of the $\mathrm{Ba}^{2+}$-induced contraction in smooth muscle cells of the rabbit mesenteric artery. J Gen Physiol 89, 215- 237 (1987)

25 Graf E, Verma AK, Gorski JP, Lopaschuk G, Niggli V, Zurini M, Carafoli $E$ and Penniston JT: Molecular properties of calcium-pumping ATPase from human erythrocytes. Biochemistry 21, 4511-4516 (1982)

26 Hai $\mathrm{C}-\mathrm{M}$ and Murphy $\mathrm{RA}: \mathrm{Ba}^{2+}$ induces contraction in swine carotid artery by mobilizing intracellular $\mathrm{Ca}^{2+}$. Am J Physiol 252, C378-C384 (1987)

27 Nagao T, Ikeo T, Sato M, Nakajima $H$ and Kiyomoto A: Effect of diltiazem on calcium- and noradrenaline-induced contractions in isolated rabbit aorta. In Recent Advances in Studies on Cardiac Structure and Metabolism, Vol 11, pp 437-440, Edited by Kobayashi T, Sato T and Dhalla NS, University Park Press, Baltimore (1978) 